\title{
一般演 題
}

\section{腎性骨症}

持続性副甲状腺機能九進症を伴った副甲状腺の惩性化症例

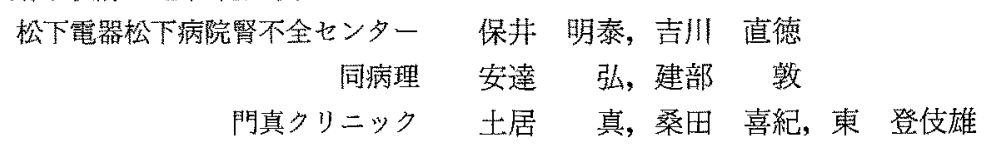

京都第一赤十字病院 小野 利彦, 岩元 則幸

腎性骨異栄養症に詨する副甲状腺严全摘術の骨格系以外に対する効果

$$
\begin{aligned}
& \text { 兵庫医科大学人工透析部 井上 聖士，長坂 肇，平岡 敬介 } \\
& \text { 荘野 忠泰, 吾妻 真幸, 湯川 進 } \\
& \text { 稲守 美紀, 井原 元, 平林 俊明 } \\
& \text { 宮本孝, 依藤 良一, 稲垣 王子 } \\
& \text { 森 熲太郎, 藤田 嘉一 }
\end{aligned}
$$

ROD に対する副甲状腺亚全摘術の有効性について

$$
\begin{aligned}
& \text { 京都第一赤十字病院泌尿器科 岩元 則幸, 小野 利彦, 山本 則之 } \\
& \text { 近藤 守寬，田端 義久，福田 豊史 } \\
& \text { 松下病院透析センター 保井 明泰 } \\
& \text { 西陣病院透析センター 青木 正, 馬㴊比砂夫 } \\
& \text { 門真クリニック 桑田 喜紀, 土居＼cjkstart真, 東 登伎夫 } \\
& \text { 馬杉医院馬校子 } \\
& \text { 久保医院 久保 泰徳 } \\
& \text { 町塚病院 町塚 昭 }
\end{aligned}
$$

活性型ビタミンD療法後の腎性骨異栄養症の臨床的検討

$$
\begin{array}{rrr}
\text { 名古屋大学第 } 3 \text { 内科 } & \text { 渡辺 } & \text { 有三, 大倉 } \\
\text { 誉済会増子病院 } & \text { 伊藤 } & \text { 晃, 山崎 親雄 } \\
\text { 偕行会名古屋共立病院 } & \text { 川原 } & \text { 弘久 }
\end{array}
$$

腎性骨異栄買症の臨床的検討（第 2 報）

重井病院内科 森脇 和久, 田中 富生, 井上裕美子

$\begin{array}{lllll} & \text { 旦 } & \text { 明良, 芳野 健, 杉本 茂 } \\ & \text { 花房 } & \text { 博, 難波 } & \text { 経雄, 重井 博 } \\ \text { 国立福山病院内科 } & \text { 近藤 } & \text { 忠亮 } & & \end{array}$

ROD に対する臨床的研究（第 1 報）透析年数並びに $1 \alpha(\mathrm{OH}) \mathrm{D}_{3}$ 投与による影響
キナシ大林病院難波啓一郎, 谷合一陽, 無鬼信 中空 博, 大林 誠一, 大林 幸 中外製薬 井上 俊明, 横関 俊材


続発性副甲状腺機能六進症を伴った副甲状腺の悪性化症 例

保井 明泰 吉川 直徳 安達 弘* 建部 敦* 土居真**桑田 喜紀**東 登伎雄**小野 利 彦***岩元 則幸***

岩元 則幸***

松下電器松下病院腎不全センター 同病理*門真クリ ニック**京都第一赤十字病院***

続発性副甲状腺機能九進症の予防と治療は, 活性型ビ タミン D, 合成カルシトニンの出現にもかかわらず，少 なからず副甲状腺亜全摘が必要である. 症例：46 歳, 男, 透析歴 11 年 3 力月. 現病歴：昭和 46 年 8 月慢性腎不全 のため定期血液透析療法開始, 導入時 $\mathrm{Ca} 8.4 \mathrm{mg} / \mathrm{d} l \mathrm{ALP}$ $13.0 \mathrm{KAU}, 47$ 年 4 月社会復帰以後自覚症状もなく維持 透析を行っていた． 52 年 1 月頃より時々膝関節痛, 腰痛 を訴えるようになり次第に増強, 54 年 8 月より活性型ビ タミンDの投与を開始した。当時 $\mathrm{Ca} 7.8 \mathrm{mg} / \mathrm{d} l, \mathrm{ALP} 20$. $4 \mathrm{KAU}, \mathrm{PTH} 5.7 \mathrm{ng} / \mathrm{m} l$ であり, 次第に骨痛関節痛は軽 滅した. 55 年 1 月頃より再び膝関節痛, 踵骨骨痛を訴元 るようになり次第に症状は悪化, 57 年 1 月には起立時階 段の昇降時に特に強く膝関節痛を訴えるようになり，57 年 8 月には PTH $22.8 \mathrm{ng} / \mathrm{m} l$ と高值を示したため, 57 年 11 月 7 日副甲状腺亜全摘術を施行した。術前 $\mathrm{Ca} 9.6 \mathrm{mg} /$ $\mathrm{d} l$, ALP 31.0 KAU, PTH $24.2 \mathrm{ng} / \mathrm{m} l$, 骨X線写真では手 指骨の骨膜下吸収像などを認め, 頸部 CT, 超音波副甲状 腺シンチでは右下副甲状腺は腫大胸骨上縁近くに位置し ていた. 摘出副甲状腺の重量は計 $4.2 \mathrm{~g}$, 右上 $0.1 \mathrm{~g}$, 右下 $3.3 \mathrm{~g}$, 左上 $0.5 \mathrm{~g}$, 左下 $0.3 \mathrm{~g}$ であった。右下副甲状腺は周 囲組織と強く療着して沾り辺緑は不整, 組織は不規則な 結合織の増生, mitosis の散在, 甲状腺組織や血管への浸 潤像がみられる副甲状腺癌であった。左上腺は結節の周 囲に太い被膜がみられ, 核の大小不同のある腺腫であり， この周辺には過形成の像がみられた。慢性腎不全に続発 した副甲状腺機能六進症の組織は 1 腺が癌腫であり， 1 腺は腺腫と他の 2 腺に共通する過形成を併存していた。 以上により過形成を背景として腺腫癌腫が発生したもの と考光る。

\section{腎性骨異栄養症に対する副甲状腺亜全摘術の骨格系以外 に対する効果}

\begin{tabular}{|c|c|c|c|c|c|c|}
\hline & 聖士 & 長坂 & 肇 & 平岡 & 敬介 & 荘野 \\
\hline & 真幸 & 湯川 & 進 & 稲守 & 美紀 & 井原 \\
\hline & 徹 & 平林 & 俊明 & 宮本 & 孝 & 依藤 \\
\hline & 王子 & 森 宗 & 頁太郎 & & 嘉一 & \\
\hline
\end{tabular}

兵庫医科大学人工透析部

慢性透析患者において高 PTH 血症が問題となるのは
主としてその骨に対する作用による.我々は過去 3 年間, 内科的に治療困難な ROD に副甲状腺垔全摘術 (PTX) を施行し, 主として骨病変の改善と骨密度, 骨塩量の増 加について報告してきた。一方 PTH は骨以外の臟器に toxic に働くことが知られており uremic toxin としての 性格が注目される様になった。そこで今回は PTX 症例 17 例について術前後の比較から骨格系以外の系への効 果について検討した.

対象は男子 4 例, 女子 13 例の計 17 例, 平均透析期間 約 8 年, 摘出した副甲状腺の平均重量は $2.7 \mathrm{~g}$ であった。

1) PTX 前に貧血は必ずしも強くないが術後は貧血 の程度が改善する，2）体重も注济全例が増加し，平均 $2.0 \mathrm{~kg}$ の増加であった. 術後の骨痛の消失, 運動量の増 加によると思われる．３） TP は PTX 後増加，特に術 前低値であった例に著しかった。血清りン值は術後低下 し，かつ，アルミゲルの服用量も減少した，血清 $\mathrm{Mg}$ 值 に著変はなかった４）血圧は収縮期，拡張期共に低下 傾向にあり，中には透析中の血圧降下が著るしく透析に 困難をきたす例が数例あった。 5 ) 神経伝導速度は術前 必ずしも低下がみられなかった。術後も不変であった。

6 ）その他搔痒の減少，皮膚の色素沈着の減少が数例に みられた。7) 軟部組織の石灰化は早期に改善がみられ たが血管壁石灰化屾不変が多かった。

\section{ROD に対する副甲状腺覀全摘術の有効性について}

岩元 則幸 小野 利彦 山本 則之 近藤 守宽 田端 義久 福田 豊史 平竹康祐 保井 明泰* 青木 正**馬㴊比砂夫**桑田喜紀 ${ }^{* * *}$ 土井 真 ${ }^{* * *}$ 東 登伎夫 ${ }^{* * *}$ 馬杉 好子 ${ }^{* * *}$ 久保 泰徳 ${ }^{* * *}$ 町塚 昭 $* * * * * *$

京都第一赤十字病院泌尿器科松下病院透析セン ター* 西陣病院透析センター** 門真クリニック*** 馬杉医院**** 久保医院 ${ }^{* * * * *}$ 町塚病院 $* * * * * *$

53 年 11 月より 58 年 2 月までに副甲状腺亚全摘術を 施行した慢性血液透析例 22 例について報告した。

1) 対象症例は男子 13 例, 女子 9 例, 透析期間 $62 \sim 137$ $\mathrm{M}$ (平均 101.2 M), 術後観察期間 3 $55 \mathrm{M}$ (平均 $22.7 \mathrm{M}$ ) であった。術前保存的治療を 21 例に行った。 その効果は 骨吸収像の消失という観点より不十分であった。2) 術 前頸部 CT を行った 18 例中 17 例に腫大した副甲状腺を 認めた。 3 ) 延 23 回の手術において, 覀全摘例 16 例, 3 腺以下切除 6 例であった。切除重量は $550 \sim 7,850 \mathrm{mg}$ (平均 3,500 mg) であった. 4) 術後著明な PTH (10 $\mathrm{ng} / \mathrm{m} l)$ の上昇を 4 例に認めたが 3 例が 3 腺以下切除で あり， 1 例は 5 腺を有する症例であった。 5 ) 血清 Al-P は術後 6 力月以降 plateau を示したが，骨レ線上骨膜下 
吸収像は長期にわたり残存する傾向にあった４）自党 的に症状の改善は著しく, 症状の残存する症例は手術的 不十分な症例であった。術後 3 例に味覚消失を認め, 今 後検討すべき課題と考元た，7）亜全摘後，副甲状腺機 能九進症の再燃を認めないにもかかわらず，骨レ線上骨 吸収像の残存する症例を認めたことは，今後検討すべき 課題と考える.

活性型ビタミン D 療法後の腎性骨異栄養症の臨床的検討

渡辺 有三大倉 譽暢 坂本 信夫 伊藤 晃 ${ }^{*}$ 山崎 親雄* 川原 弘久**

名古屋大学第 3 内科 衆済会增子病院 ${ }^{*}$ 偕行会名古屋 共立病院**

腎性骨異栄養症 (ROD) の中で，二次性副甲状腺機能 六進症 (SHPT) に対する活性型ビタミンDの効果は顕 著である。しかしながら内科治療に抵抗性となり副甲状 腺亚全摘術 (PTX) が必要な症例も多い.PTX 症例は, 透析患者全体と比較して，透析期間が有意に長く，年齢 は有意に若いが，329例の全身骨X線所見の検討では， SHPT の所見が認められる症例は, 透析療法導入後 2 年 までの早期と, 導入後 6 年以上の長期例に多かった。透 析導入早期から SHPT の所見が顕性になってくる背景 には, 保存期腎不全の治療方法に問題があると考えられ, ROD に対する積極的な予防的治療が必要である。一方, 活性型ビタミン Dを保存期腎不全患者に投与すると，腎 機能の悪化する例があると考えられている.今回我々は, 保存期腎不全患者に対して $1 \alpha-\mathrm{OH}-\mathrm{D}_{3}$ が腎機能に与兄 る効果を retrospective に検討し, 更に食事療法につい ても検討して以下の結論を得た。

1) ROD は保存期腎不全の頃より始まって招り予防的 治療が必要である。 2) $1 \alpha-\mathrm{OH}-\mathrm{D}_{3}$ 治療群と非治療群と の間には, 腎機能悪化率に差が認められなかった。しか 乙 $1 \alpha-\mathrm{OH}-\mathrm{D}_{3}$ 単独療法群は, $\mathrm{Ca}$ 補充療法やアルミゲル を併用した群と比較して腎不全の進展が有意に促進され る. 3 ）腎機能悪化には， $\mathrm{Ca} \times \mathrm{P}$ 積の上昇，血清無機燐 の上昇が関与する，4）高 $\mathrm{Ca}$ 低 $\mathrm{P}$ 食を処方し, 食物中 の $\mathrm{Ca} / \mathrm{P}$ 比を高める事は, 腸管での $\mathrm{P}$ 吸収を抑制し, 一 種の phosphate binder として利用できる。また Ca 代 謝の面からも有用である。 5 ) 保存期腎不全患者に $1 \alpha$ $-\mathrm{OH}-\mathrm{D}_{3}$ を使用する際, $\mathrm{Ca}$ の補充, アルミゲルの併用が 望ましい.

\section{腎性骨異栄養症の臨床学的検討（第 2 報）}

森脇 和久 田中富生 井上裕美子 旦 明良 芳野 健杉本茂 花房 博 難波 経雄 重井 博 近藤 忠亮*
重井病院内科 国立福山病院内科*

慢性血液透析患者の $\alpha \mathrm{D}_{3}$ 投与群，非投与群における $\mathrm{Ca}, \mathrm{P}, \mathrm{Al}-\mathrm{P}, \mathrm{C}-\mathrm{PTH}$, 手指骨 X-P 分類 $\left(0_{1}, 0_{2}, 0_{3}\right.$, I, II, III), MD 法等の経時的変化について報告する.

〔対象〕 99 例(男 67, 女 32 ), 平均年齢 47.5 歳, 平均 透析期間 $57.4 \pm 33.8$ 力月. $\alpha \mathrm{D}_{3}$ 非投与群 52 例, 投与群 47 例. 一定量継続投与群 40 例 $(0.25 \mu \mathrm{g} 7$ 例, $0.5 \mu \mathrm{g} 5$ 例, $1.0 \mu \mathrm{g} 28$ 例, 平均投与期間 $26.4 \pm 21.8$ 力月), 投与 量変更群 7 例. 透析液 $\mathrm{Ca}$ 濃度 $3.5 \mathrm{mEq} / l, \mathrm{C}-\mathrm{PTH}$, 手指 骨 X-P 分類，MD法は 56 年 10 月より 3 回実施（それ 以前より継続投与している群 20 例, 以後新規投与した群 22 例).

〔結果〕1) Ca は投与群では徐久に増加し非投与群よ り高值を示したが投与量の多少による差は認めなかっ た．2） P は投与群，非投与群とも経時的な変化を認め なかった。 3 )Al-P は投与群で投与後 1 年間は下降傾向 を示したが 1 年以後は上昇傾向を認めた。非投与群では 年月とともに上昇傾向を示した，投与量の多少による差 は認めなかった４）投与量を增量した 6 例では $\mathrm{Ca}$ は 上昇， $\mathrm{Al}-\mathrm{P}$ は下降する傾向を示したが $\mathrm{P}$ は一定の傾向 を示さなかった５）C-PTH は投与群，非投与群とも 上昇傾向を認めた。 6) MCI は新規投与群では増加傾向 を認めた。継続投与群，非投与群とも減少傾向を認めた が，継続投与群では減少率の抑制を認めた。 $\Sigma$ GS/D は 非投与群では減少傾向を認めたが，継続投与群，新規投 与群ともやや増加傾向を示した。7) 手指骨 X-P 分類 では非投与群で 1 年後 $\mathrm{O}_{3}$ が増加したが, 新規投与群, 継 続投与群では変化を認めなかった. 以上 $\alpha \mathrm{D}_{3}$ 投与群では 非投与群に比し腎性骨症の進行抑制の効果は認められた が，これを治療させる効果は不十分で，カルシトニン， $24,25(\mathrm{OH}) \mathrm{D}_{3}$ 等との併用療法など骨形成を促進させる 療法の十分な検討が必要と思われた。

\section{ROD に対する臨床的研究（第 1 報）透析年数並びに $1 \alpha$ $(\mathrm{OH}) \mathrm{D}_{3}$ 投与による影響}

難波啓一郎 谷合一陽 無鬼信中空博 大林 誠一 大林 幸 井上 俊明* 横関 俊材* キナシ大林病院 中外製薬*

透析歴㧍よび $1 \alpha(\mathrm{OH}) \mathrm{D}_{3}$ 投与により血清 $\mathrm{Ca}, \mathrm{P}, \mathrm{Al}$ -P, PTH, 自覚症並びに MD 法にて算出されたパラメー ターを用いて ROD について比較検討した。

〔方法〕当院透析患者 270 名中 40 例（男 26 例，女 14 例)を抽出し, 11 例の非投与群と 29 例の投与群と比較検 討を行った。透析歴は最長 142 力月, 最短 9 力月であっ た. $1 \alpha-(\mathrm{OH}) \mathrm{D}_{3}$ 投与量は血清 $\mathrm{Ca}$ 值 $8.4 \sim 10.6 \mathrm{mg} / \mathrm{d} l$ k なるよう適当量を投与し, 各月に血清生化学的検㚗と 
6.12 力月とに MD 法施行した. 自覚症は患者へのアン ケート調查により判定をした。

〔結論〕透析歴が長くなるにつれて有意の変化を示す のに, Al-P の增加, $\Delta \mathrm{GSmax}, \Delta \mathrm{GSmin}$ の低下があり, 血清 $\mathrm{Ca}, \mathrm{P}, \mathrm{PTH}, \Sigma \mathrm{GS} / \mathrm{D}$ は, 有意の差を認めなかっ た.

$1 \alpha(\mathrm{OH}) \mathrm{D}_{3}$ 投与による血液生化学的変化にては，投 与前との比斡にて, Ca 值は有意の上昇を, Al-P, PTH に ては有意の低下を認めた。また投与群，非投与群の間で
は $\mathrm{Ca}$ 值に扔いてのみ有意の差がみられた。

$\mathrm{MD}$ 法にては投与群, 非投与群間に抒いて 6 力月, 12 カ月とも $\mathrm{MCI}, \mathrm{\Sigma} \mathrm{GS} / \mathrm{D}, \Delta \mathrm{GSmax}, \Delta \mathrm{GS} \min$ に, 有意 の差はみられなかった。 また投与前と比較して, 投与群 の $\mathrm{MCI}$ のが有意の低下を示し, 検討を要すると思わ 机た。

また骨痛扔よび骨パターンの変化についても検討を 行ったが, 投与群, 非投与群間に有意の差は認められな かった。

\section{討 論}

井上（兵庫医大）保井先生にお聞きしたいのですが， アデノカルチノーマだというような御発表で, 私もパラ サイロイドの組織は余りよくは知らないのですが, 普通 のハイパープラジアではなしに，パラサイロイドのアデ ノーマの組織の分類の仕方に, 本当のアデノーマと シュードアデノーマというような分類がございまして, 本当のアデノーマのところはパラサイロードの腺の組織 側比結合織と被膜がなくて，周囲の組織とそのまま直接 移行しているということとか, それからミトーシスの像, あれはカルチに特有なものではなくて，アデノーマだけ でもところどころ出るというような記載はございます。 それも，離れてなおかつ，マリグナントなアデノカルチ ノーマだったのかというふうなことを御質問したのです מ゙.

保井 内分泌の癌というのは, 非常に病理でも難しい そうですし，ここで診断をやった基準は，結合織の增生 があるということと，それからマイトージスがあるとい うことと，それから浸潤がある。この症例では，血管へ の浸潤と甲状腺組織への漫潤が見られたわけです。その 3 点で一応悪性化という診断をしたわけです.

富田 私も, 確加組織学的には悪性かどうかという のは非常に難しいと思うのですが，1つは臨床的な経過 を見ていただくということで，プライマリーハイパーパ ラの場合は, 悪性のものが進展に非常に速いとか, 䠰床 的に非常に悪いとかいうようなこと，いろいろございま すので，そういう臨床的な経過も1つ追っていただきた いと思います。

渡辺 岩元先生にちょっとお伺いしたいのですが， 22 例をやられて 16 例が成功例ということですが, 先生方, 抢やりになるときに，必ず最初に 4 腺を確認してから， 取るのを決劣とか，そういうのは扔やりになるので しょうか。我久, 愛知県癌センターの高木, それから名 古屋大学第 1 外科の前田らと，常に共同で，もう既に 30
例を超える副甲状腺手術をやっておりますが，いまだ， 再手術を必要とした症例は 1 例だけしかないものですか ら，ちょっとそこの点が疑問があったものですから，お 教え願いたい。

岩元一応術前にCT を用以まして画像診断はして扔 りますけれども, その診断で 4 腺確認し得るケースと, 実際は 1 腺だけ肥大していて，臨床的に取りにいかなけ ればならないというふうな我々のケースですけれども， そういった中で, 術前に 4 腺を確認して取るということ は, 今, 現実的に不可能だと思います。術中にも一応 4 腺を確認してと努めているわけですけれども，実際は 3 腺以下になった症例がスライドに示したようにあるわけ です.

渡辺 術前で 4 腺を確認するのはまず無理ということ は，それは私も考えています，CT で確認できる副甲状 腺の大きさというのは，かなり大きなものしか出ません ので，通常，4腺が全部出るはずがないということを思 うのですが，その中でも手術の後の PTH の下がりとか そういうのが, 少し, 我々の経験と比べて恶いような気 がして, 取り残しが, $50 \mathrm{mg}, 100 \mathrm{mg}$ というのがもつと たくさん残っているのではないかという印象だったので す.

岩元そのことで, 今回も非常に内部的に議論になっ たのですけ机ども，奏際のところ，2月までに 22 例行い まして, 術中に 5 腺確認した症例が 1 例と, CT で後で 下がりが悪いというので, もう一度確認したら, サイロ イドの中にもう一つ見落としていたというのがあったの です.ラドックらの報告に従って，ほとんど実質を大体 $1 \mathrm{mg}$ ぐらいのスライスで切ってしまって, 害際は $50 \mathrm{mg}$ も残っていないというふうにこっちは確認しているわけ ですけれども。

中村（東大）井上先生に扔伺いしたいのですけれど も，私もメタボリックボーンディジーズの臨床症状とい 
うものに興味を持っているのですが，ナーブコンダク ションベロシティを极測りになった時に, 筋電図も㭁や りになったそうですが，大体この PTH が高い時という のは, 恐らくものすごいディスタールのイントラムスク ラールのところで何かだろうと。で, ロングデュレーショ ン涩い成績が出たり,いるんなことがあるのですが, 夕一 ミナルレイテンシーは，先生扔測りになりましたでしょ うか.

井上 筋電図は，すべてではないのですが，とって拉 りますが，穴の辺の検討を余りしていません。

中村 それと, 私, 全くこれは素人なのですけれども， 副甲状腺全摘された後の臨床症状の改善というのは, 検 査值の改善と此べて，またはプライマリーの時の摘出の 後の臨床症状の改善に比べて, 何か検查值の割りには改 善が遅いとか, 逆に検查值はまだ改善していないにもか かわらず, 臨床症状の改善が速いとか, そういう特性は ありますでしょうか。

井上 全摘であった例はありませんので, 亚全摘の例 で申し上げますと，最初に改善してまいりますのが，も う骨痛が取れるわけです。これが術後翌日とか翌々日と か, そういう日の単位で, 取れてまいりまして, 最初私 ぞも, 少し疑問に思っていたので, 首が痛いので, それ にマスキングされているのではないかと赛は思ったので すが，そうではなくて，ベッドの上で足を動かしまして も明らかに痛みが取れていると，ほかの先生方の話を聞 きましても，骨が一番最初に取れるという先生方が非常 に多いので，多分，確かにそれが一番最初に取れている のだと思います。それから，検查值の割りに所見がいつ までも残るというのは, ラガージャージーアピアランス
ですね。これはアビオリに言わせますと，病的なラガー ジャージーアピアランスと, 治ってきつつあるラガー ジャージーアピアランス㤬違うのだというふうなことを 彼は言っておるわけですけれども，私ども，元こまでは ちょっとよく行からないのですが，一翻長く残ります。 ほかの所見はきれいになくなって，西れだけ残ります。 あれはどうもおかしいですね。

川原 キナシ大林病院の方に抒教えいただきたいと思 いますが, 先ほど私どもの渡辺が保存療法に限って今日 のところ報告いたしましたけ狄ども， $\alpha$ ロール，活性型 ビタミンDを使っていく時に, 活性型ビタミンDだけで Caを上げていくというの性, 非常に我々は抵抗を感じて いるわけでありまして，といいますのは，かつて透析研 究会, 方るいは日本腎㵴病学会で発表しましたけれども， 透析患者に Ca バランステストを行いますと，かなりネ ガティブになっているわけです。したがいまして，この

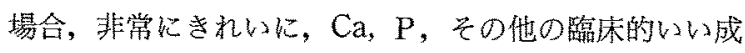
績が出ておりますけれども，大体どのくらいのCaを，

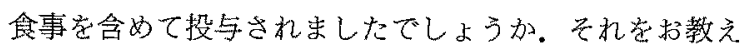
願いたいと思いますが。

難波 今回 $1 \alpha(\mathrm{OH}) \mathrm{D}_{3}$ が効果があったかどうかと いうことを出すことが，第一義的な目的であったと思い ます，それで，できるだけ条件を同じにするために，そ の患者さんには加えてなかったわけですけれども，ほか の患者さんにはもちろん Ca ほ投与しております。大体 炭酸 $\mathrm{Ca}$ で, $1000 \mathrm{mg} /$ 日ぐらいが必要だろうと思います。 それで MCI だけ低下するのが，もう1つ自分としては 納得いかなかったのですけれども，その辺にも原因があ るのではないかと考えて抒ります。 